\title{
Fuzzy Dynamic Programming Based Solar-Thermal Load Scheduling of Andhra Pradesh Power Generation using Matlab
}

\author{
P V Narendra Kumar, Ch Chengaiah, J V K Prasad
}

\begin{abstract}
India, being the world's third greatest power producer with total given farthest purpose of $344.69 \mathrm{GW}$, contributing sixty eight percent of heat capability. In Republic of India, most extreme power is made from Thermal Generating Power Stations. The fuel for Thermal Generating Power Stations is coal. Step by step, contamination has been increasing and accessibility of coal is decreasing. Henceforward it's vital to minimize the age of Power from heat plant. It's prudent to make and use sun high-powered power. It's vital to provide a lot of influence from sun primarily based plant to satisfy base burden and on these lines modification heat power. The discourse is finished in perspective on the money stinting, procedure speed up and expandability which might be accomplished by utilizing Fuzzy logic Controller. This Paper demonstrates a utilization of the symbolic logic to the problems of Unit Commitment and load planning with a specific final objective to seek out age about to such a degree, that absolutely the age price may be ideal by exchanging on daylight primarily based age. during this paper, as a discourse investigation, symbolic logic programming primarily based economic load dispatch technique is planned, actualised and tried by utilizing MATLAB surroundings to exhibit the possibleness and points of interest of utilizing symbolic logic controller in facility applications. Ideal positions of this techniques is that the ability to upgrade over a progressively noticeable arrangement of operating conditions the searching out comes demonstrate that the planned technique furnishes doable arrangement with Brooding and avian reserve funds and legit for real time operations.
\end{abstract}

Keywords- APGENCO, Thermal Power Generation, alternative energy Generation, Unit Commitment, Load planning, Dynamic Programming, fuzzyLogic controller, optimization, MATLAB

\section{INTRODUCTION}

The Government of Andhra Pradesh was one in all the pioneer states to begin the facility half changes in 1998. The past Andhra Pradesh State Electricity Board (APSEB) was unbundled into six substances to target the middle task of Power Generation (APGENCO), Power Transmission (APTRANSCO) and Distribution (APDISCOMS). Brooding avain live of speculations were created for structure up ordinance, reinforcing transmission and dissemination organize, fashionable feeder isolation, misfortune decrease and rising nature of influence provide. beginning at 2014, the all out ordinance of Andhra Pradesh is eight,307 MW in line with management distribution. Existing inexhaustible limit is

Revised Manuscript Received on August 19, 2019.

P V Narendra Kumar, Research Scholar, Department of EEE,Sri Venkateswara University, Tirupati, Andhra Pradesh, India

Dr Ch Chengaiah, Professor, Department of EEE, Sri Venkateswara University, Tirupati, Andhra Pradesh, India

J V K Prasad, Divisional Engineer, APGENCO, Andhra Pradesh, India around one,397 MW (Wind - $777 \mathrm{MW}$, star - seventy seven MW, Others - 543 MW).As of December 2018, Andhra Pradesh had AN all out introduced management ordinance of twenty three, $051 \mathrm{MW}$. Out of the twenty three, $051 \mathrm{MW}$, state utilities contributed six,367.75 MW, personal utilities contributed thirteen,904.48 MW and focal utilities contributed one, $984.87 \mathrm{MW}$. With a commitment of thirteen,857.80 MW, heat power diagrammatical the foremost noteworthy supply of the overall introduced management ordinance of the state, trailed by property power supply with a commitment of six,598.43 MW. The state has ten hydro power extends underneath task and a couple of underneath development. Moreover, the state has one operational breeze management venture. World's biggest single-area daylight primarily based park is settled in Kurnool venue. The venture concerned a speculation of Rs 7,000 large integer (US\$ one.08 billion) and is presently utterly operational. In defrayal range 2017-18, the regime declared styles to contribute Rs 4,311 large integer (US\$ 669.13 million) for the advancement of the vitality space within the state. The law-makers had supported putting in place of six light- water atomic reactors within the state in 2016. The atomic reactors are going to be came upon in Kovvada and can have a limit of one,208 MW every. As of Jan 2018, exchanges with George Westinghouse power service square measure in advancement to the touch base at a sensible proposition. Amid 2015-16, the whole specialised and business misfortunes declined to ten.29\% once contrasted with eleven.81\% in 2014-15. moreover, amid an identical amount the regime increased an additional limit of 2290 MW of intensity within the state the regime is that specialize in improvement of an additional limit of $4800 \mathrm{MW}$ within the coming back three years the whole introduced utility power limit is $23051 \mathrm{MW}$ within the state.

Table 1: put in capability of Thermal Power Stations

\begin{tabular}{|l|l|l|l|}
\hline Name of the Thermal Power Station & Operator & Sector & $\begin{array}{l}\text { Capacity } \\
\text { (MW) }\end{array}$ \\
\hline Simhadri Super TPS & NTPC & CENTRAL & 2000 \\
\hline Dr Narla Tata Rao TPS & APGENCO & STATE & 1760 \\
\hline Rayalaseema TPS & APGENCO & STATE & 1650 \\
\hline Sri Damodaram Sanjeevaiah TPS & APGENCO & STATE & 1600 \\
\hline Vizag TPS & HINDUJA & PRIVATE & 1040 \\
\hline Simhapuri TPS & SEPL & PRIVATE & 600 \\
\hline Meenakshi TPS & MEPL & PRIVATE & 1000 \\
\hline Sembcorp TPS & SEIL & PRIVATE & 1320 \\
\hline SGPL TPS & SGPL & PRIVATE & 1320 \\
\hline TOTAL: & & $\mathbf{1 2 2 9 0}$ \\
\hline
\end{tabular}

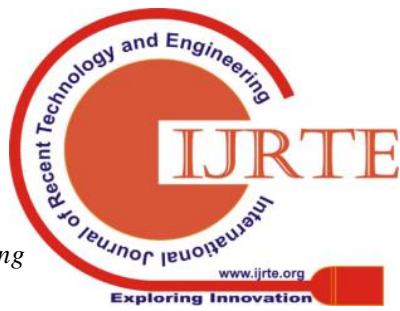




\section{FUZZY DYNAMIC PROGRAMMING BASED SOLAR-THERMAL LOAD SCHEDULING OF ANDHRA PRADESH POWER GENERATION USING MATLAB}

Coming up next square measure the summation of by and by introduced consolidated Cycle turbine management plants and diesel engine power plants within the state. Anyway an oversized range of those power plants aren't operating because of non-accessibility of volatilized hydrocarbon and impressive expense of fluid energizes.

Table 2: put in capability of Gas Power Stations

\begin{tabular}{|l|l|l|l|}
\hline Name of the Power Station & Operator & Sector & Capacity(MW) \\
\hline APGPCL Power Station & APGPCL & Joint & 272 \\
\hline Lanco Kondapalli PS & Lanco Infratech & Private & 1466 \\
\hline Gauthami PS & GVK & Private & 464 \\
\hline Konaseema PS & KGPL & Private & 445 \\
\hline Vemagiri PS & GMR & Private & 370 \\
\hline GMR Rajamundry & GMR & Private & 768 \\
\hline Samrlakota PS & Reliance & Private & 2620 \\
\hline Godavari Gas PS & APGENCO & STATE & 216 \\
\hline Jegurupadu PS & GVK & Private & 229 \\
\hline Spectrum PS & Spectrum & Private & 209 \\
\hline GMR PS & GMR & Private & 237 \\
\hline LVS Diesel PS & Greenko & Private & 37 \\
\hline Panduranga PS & PESPL & Private & 116 \\
\hline RVK Energy PS & RVK Infra & Private & 436 \\
\hline Sriba PS & Sriba Industries & Private & 30 \\
\hline Silk Road PS & EID Infra & Private & 35 \\
\hline Sri Vathsa PS & Asian Genco & Private & 17 \\
\hline TOTAL: & \multicolumn{2}{|l}{} \\
\hline
\end{tabular}

Table three shows the list of major electricity power plants in Andhra Pradesh.

Table 3: put in capability of Hydro Power Stations

\begin{tabular}{|l|l|l|}
\hline Name of the Power Station & Unit Wise Capacity (MW) & $\begin{array}{l}\text { Total } \\
\text { Capacity(MW) }\end{array}$ \\
\hline Chettipeta mini hydel & $2^{*} 0.5$ & 1.00 \\
\hline Donkarayi P H & $1^{*} 25$ & 25.00 \\
\hline Hampi Canal P H & $4^{*} 9$ (AP Share-28.8) & 28.80 \\
\hline Lower Sileru & $4 * 115$ & 460.00 \\
\hline Manchkund & $3^{*} 17+3 * 23$ & 84.00 \\
\hline Ngarjuna Sagar Right Canal P H & $3^{*} 30$ & 90.00 \\
\hline Ngarjuna Sagar TailPond P H & $2^{*} 25$ & 50.00 \\
\hline Penna Ahobilam & $2^{*} 10$ & 20.00 \\
\hline Srisailam Right Bank & $7 * 110$ & 770.00 \\
\hline Tungabadra Dam PH & $4^{*} 9$ (AP Share-28.8) & 28.80 \\
\hline Upper Sileru PH & $4 * 60$ & 240.00 \\
\hline & & 1797.60 \\
\hline
\end{tabular}

The state has all out introduced sun primarily based power limit of two,600 MW beginning at thirty Gregorian calendar month a pair of018 put in electrical phenomenon limit in Andhra Pradesh is quite 2,590 MW as on thirty Gregorian calendar month 2018. In 2015, NTPC concurred with Transco to introduce the 250-MW NP Kunta immoderate Mega alternative energy Project shut Kadiri in Anantapur District. In October 2017, one thousand MW was charged at Kurnool immoderate Mega alternativenergy Project that has become the world's biggest daylight primarily based station around then. In August 2018, larger Visakhapatnam approved a a pair of MW lattice associated drifting daylight \{based mostly |primarily based\} task that is biggest operational skimming sun based PV venture in Republic of India. NTPC Simhdri is desirous to introduce twenty five MW drifting sun primarily based PV plant on its installation repository. In February 2019, two hundred MW was approved at Ananthapuram - II sun orienting park settled shut Tadipatri. nevertheless on top of undertakings, there square measure regarding eighty nine.1 MW very little Hydro plants, almost 421.14 MW pulp, bio-mass co-age and bio-mass primarily based tasks, about 78.79scaled down power plants (network associated) and virtually sixty seven.20 MW alternative ( matrix associated) plants obsessed with disengaged gas wells, squander heat, fashionable waste, town squander, then on in camera sector.
Table 4: put in capability of alternative energy Stations

\begin{tabular}{|l|l|l|l|}
\hline $\begin{array}{l}\text { Name of the Solar Power } \\
\text { Station }\end{array}$ & Opertor & Sector & $\begin{array}{l}\text { Capacity } \\
\text { (MW) }\end{array}$ \\
\hline $\begin{array}{l}\text { NP Kunta Ultra Mega Solar } \\
\text { Power Plant }\end{array}$ & NTPC & CENTRL & 500.00 \\
\hline Amruth Solar P P & Amruth Ventures & PRIVATE & 1.00 \\
\hline MEIL Solar Thermal PP & $\begin{array}{l}\text { Megha Engineering } \\
\& \text { Infrstructures } \\
\text { Ltd }\end{array}$ & PRIVATE & 50.00 \\
\hline $\begin{array}{l}\text { Kurnool Ultra Mega Solar } \\
\text { Power Plant }\end{array}$ & NTPC & CENTRL & 1000.00 \\
\hline $\begin{array}{l}\text { Anantapuramu - II Mega Solr } \\
\text { Park }\end{array}$ & APGENCO & STATE & 200.00 \\
\hline TOTAL: & \multicolumn{3}{|l}{} \\
\hline
\end{tabular}

The state has total put in alternative energy capability of four,088 MW as on thirty Gregorian calendar month 2018

Table 5: put in capability of alternative energy Stations

\begin{tabular}{|l|l|l|l|}
\hline $\begin{array}{l}\text { Name of the Wind Power } \\
\text { Station }\end{array}$ & Operator & $\begin{array}{l}\text { Unit Wise } \\
\text { Capacity }\end{array}$ & $\begin{array}{l}\text { Total Capacity } \\
\text { (MV) }\end{array}$ \\
\hline Ramagiri Wind Mills & APGENCO & $10^{*} 0.2$ & 2.00 \\
\hline Narmada Wind Farms & CLP Wind Farms & $1^{*} 50.4$ & 50.40 \\
\hline Puthlur RCI Wind Farms & Wescare Ltd & $1^{*} 20$ & 20.00 \\
\hline TOTAL: & 72.40 \\
\hline
\end{tabular}

These power plants aren't covering captive management limit in numerous businesses that aren't lattice associated. what is a lot of, there square measure endless diesel generator sets introduced within the state for stay by provide and crisis management providedesires amid power blackouts

\subsection{Thermal Power Stations}

In a take a look at management framework, Power plants aren't organized at a comparable detachment from the purpose of convergence of burdens and their fuel prices square measure explicit. moreover underneath traditional operating conditions, the ordinance has to modify burden request and misfortunes. Therefore, there square measure numerous choices for transcription the age price. With broad between relationship of electrical frameworks, the imperativeness crisis on the world and reliable rising in prices, it's astonishingly principal to scale back the running charges of electrical essentiality i.e., diminishment of fuel use for handling a specific burden request. during this method, the thought nowadays is on redesigning the age price of intensity stations. within the gift condition, handling the facility request and overhauling age has remodeled into a necessity. Unit Commitment (UC) and cargo planning(LS) in hierarchy suggests the advance issue for selecting the On/Off states of making units that restricts the age price subject to sort of stipulations for a given time. The course of action of the unit commitment downside (UCP) is AN astounding streamlining issue [1]. the correct arrange of the UCP may be gotten by all details of every and each conceivable mixture of generating units, that may bevery stupendous range [2]. during this paper, talked regarding the UC issue [3], [4] is to diminish the generating prices known with a bundle of frame work and unit imperative for the given skyline. From the essential trademark bend of a unit is communicated relating to rupees each hour with yield of power [5]. it's traditional that the age price, $\mathrm{Ci}$ for unit" $i$ " at any reserved measure could be a quadratic limit of the generator management yield.

$$
\mathrm{Fi}(\mathrm{Pg} \mathrm{i})=\quad \frac{1}{2} a i P g i^{2}+b i \mathrm{Pgi}+d i
$$


Where $\mathrm{Fi}(\mathrm{Pgi})=$ Fuel price with relevance generated Power

Pgi=Generated Power from ith generator Unit

ai,bi =variable price constants

$\mathrm{di}=$ fixed price constant and

the generated power at every hour should be up to the Load and losses during a facility [6].

$$
\sum_{i}^{n} P g i=P d+P l
$$

Generally, the generated power of the unit is underneath its lower and higher limits Pgi min Pgimin $\leq P g i \leq$ Pgimax

\section{2 alternative energy Stations}

Stations daylight primarily based vitality may be modified over into differing kinds of vitality, for instance, heat and power. Throughout the decade, British people stargazer Herschel utilized a sun high-powered heat authority box (a convenience that assimilates daylight to assemble heat) to cook nourishment amid AN endeavor to Africa. Today, people utilize the sun's vitality for tons of things. Sun orienting vitality may be utilised to heat a liquid, for instance, water in sun orienting gatherer boards. . Basic kinds utilize level authority boards mounted on a south-bound upper side or divider, every with simple unfold to concede daylight. Water flows through channels or pipes within every board. at intervals is generally painted dark, since dark surfaces promptly assimilate heat. The water is warm, and at the moment the high worker water is siphoned to a heat money handler that separates the heat to be used within the house. Sun high-powered vitality will likewise be utilized to make power in electrical phenomenon (PV) cells. A PV cell might management your range cruncher. electrical phenomenon cells square measure product of semiconductors, like those accustomed create computer chips. As of shortly agony these cells were altogether respects costly to deliver. Be that because it might, they're still simply around 10-15\% productive. Sun high-powered vitality may be modified over to heat (or heat) vitality and used to: Heat water to be used in homes, structures, or pools. heat areas within nurseries, homes, and totally different structures. Sun primarily based vitality may be modified over to power in 2 totally different ways: this transformation daylight squarely into power. PV frameworks square measure often utilized in remote areas that aren't related to the electrical network. they're likewise accustomed management watches, adding machines and lit street signs. during this day lightweight is modified over to power during a detour. it's 1st modified over to technician vitality and later to electrical vitality. At the purpose once $\{\mid$ the heat $\}$ from daylight primarily based heat gathers $\{$ is employed |is used\} to warm a liquid that produces steam that's utilized to regulate generator. Out of the fifteen operating within the u. s. towards the top of 2006, ten of those square measure in American state and five in Arizona. No measurements square measure being gathered on daylight primarily based plants that turn out underneath one power unit of power, thus there can be litter sun orienting plants in numerous states.

Photovoltaic is that the immediate amendment of sunshine into power at the nuclear dimension. a number of materials complete sun primarily based electrical generating units

show a property referred to as the photoelectric impact that produces them assimilate photons of sunshine and discharge electrons. At the purpose once these free electrons square measure caught, an electrical flow results which will be utilised as power. The physical phenomenon impact was 1stnoted by a French scientist, Edmund Becquerel, in 1839, UN agency found that specific materials would produce very little measures of electrical flow once given to lightweight. In 1905, Einstein depicted the thought of sunshine and also the physical phenomenon impact on that electrical phenomenon innovation is predicated, that he later won a accolade in material science. The principal electrical phenomenon module was worked by Bell Laboratories in 1954. it had been charged as a solar array And was typically solely an anomaly because it was too expensive to even think about gaining across the board use. throughout the Sixties, the house business began to create the principal real utilization of the innovation to convey management on board rocket. Through the house programs, the innovation propelled, its unwavering quality was came upon, and also the expense began to decrease. Amid the vitality emergency throughout the Seventies, electrical phenomenon innovation picked up acknowledgement as a wellspring of intensity for non-space applications.

\section{3 operating Principle:}

Daylight is formed out of photons, or particles of sun high-powered vitality. These photons contain totally different measures of vitality comparison to the various wavelengths of the sun primarily based vary. At the purpose once photons strike a electric cell, they may be mirrored, go directly through, or be assimilated. simply the preserved photons provide vitality to provide power. At the purpose once enough daylight (vitality) is consumed by the fabric (a semiconductor), electrons square measure off from the material's iotas. Exceptional treatment of the fabric surface amid collecting makes the front surface of the cell more and more awake to free electrons, that the electrons unremarkably move to the surface. At the purpose once the electrons leave their position, openings square measure framed. At the purpose once varied electrons, every transfer a electric charge, travel toward the front surface of the cell, the following awkwardness of charge between the cell's front and back surfaces makes a voltage potential just like the negative and positive terminals of A battery. At the purpose once the 2 surfaces square measure associated through AN outer burden, power streams

\section{METHODOLOGY}

For implementation of symbolic logic primarily based Economic Load Dispatch (FLBELD) is dead within the following method and is explained during a transient as follows.

Pre process

Fuzzification

Rule-based creation

Fuzzy logical thinking mechanism 

PRADESH POWER GENERATION USING MATLAB

\section{Defuzzification}

Table 6: Thermal Power Stations with their capacities underneath APGENCO

\begin{tabular}{|l|l|l|l|}
\hline Name of the Thermal Power Station & Operator & Sector & Capacity(MW) \\
\hline Dr Narla Tata Rao TPS & APGENCO & STATE & 1760 \\
\hline Rayalaseema TPS & APGENCO & STATE & 1650 \\
\hline Sri Damodaram Sanjeevaiah TPS & APGENCO & STATE & 1600 \\
\hline TOTAL: & & & $\mathbf{5 0 1 0 . 0 0}$ \\
\hline
\end{tabular}

In preprocessing block, ranges square measure documented for all inputs and outputs that show the relevant positions of the controlled method i.e., recognizing the factors (Inputs, States and Outputs) of the plant. Determination of flossy management factors depends on nature of intensity framework to figure any generator unit financially and to convey the heap on each generator unit. Fuzzification is that the method toward dynamical over a recent data variable into their relating flossy factors. per se it will decision the Fuzzification because the method toward shelling out the participation capacities to incorporate even as yield factors. each one of the FLBELD data and yield signals have range of linguistics factors and every phonetic variable is said with one participation work. the number of history factors differs relying upon the applying. dependent on the difficulty to be apprehended, rules square measure planned utilizing Input and Output factors and people square measure place away in guideline base of a flossy. The Fuzzified esteems square measure then utilized by derivation motor to assess the management rules. that suggests, the estimations of Input factors of flossy controller square measure befittingly joined with the vital flossy knowledge standards to form surmising with regard to the yield factors. Here, rules square measure planned utilizing IF, so Rule style. Defuzzification implies the procedure of transformation of flossy qualities into the recent qualities. that suggests the result from guideline base and Fuzzy logical thinking Engine could be a flossy esteem that is modified over into a solitary esteem. For this example, a center of mass Defuzzification strategy is chosen for dynamical over every data acquire from the surmising motor that is communicated as so much as flossy set. At long last this flossy esteem is modified over into the recent esteem. With this examination, during this paper, think about six manufacturing stations with parameters recorded within the Table6 and Table7 and also the heap request of the Thermal Power Generating Station and alternative energy on the facility framework is not steady and so it fluctuates on the station each currently so. Be that because it might, the Thermal Power Generating Stations square measure utilized to satisfy base lo From Table.8 Thermal and alternative energy Stations with their skills square measure thought of. because the selected purposeful Thermal Power Generating Station and alternative energy Generating Station is of large limit, it includes intensive range of counts. henceforward this multifarious nature of subsiding all the scientific conditions ought to be potential by composing a program in MATLAB with the thought of Dynamic Programming strategy is used to illuminate Economic Load Dispatch of a viable Thermal Power Generating Station and alternative energy Generating Station. With the aftereffects of MATLAB program it's Generating Stations is taken into account. The Load request

recognized because the amount of counts increments with increasing limit of a station And range of generators is distinguished as a negative mark which might be overcome with flossy Logic Controller and it's structured to such an extent that to satisfy the given burden would like. Anyway With the aftereffects of MATLAB program, the planned Fuzzy methodology is empower to supply declare a heap on the station distinctive the number of generators needed to satisfy the given burden would like And what can be the manufacturing intensity of an each generator at that specific hour, in this manner taking care of the problems of Unit Commitment and cargo planning with ideal expense

Table 7: Major alternative energy Stations with their capacities

\begin{tabular}{|l|l|l|l|}
\hline Name of the Solar Power Station & Operator & Sector & Capacity \\
& & & (MW) \\
\hline NP Kunta Ultra Mega Solar Power Plant & NTPC & CENTRL & 500.00 \\
\hline Kurnool Ultra Mega Solar Power Plant & NTPC & CENTRL & 1000.00 \\
\hline Anantapuramu - II Mega Solr Park & APGENCO & STATE & 200.00 \\
\hline TOTAL: & & & \\
\hline
\end{tabular}

Table 8: Thermal Stations with their capacities

\begin{tabular}{|l|l|l|l|}
\hline Name of the Power Station & Operator & Sector & Capacity \\
(MW) & & \\
\hline Dr Narla Tata Rao TPS & APGENCO & STATE & 1760 \\
\hline Rayalaseema TPS & APGENCO & STATE & 1650 \\
\hline Sri Damodaram Sanjeevaiah TPS & APGENCO & STATE & 1600 \\
\hline $\begin{array}{l}\text { NP Kunta Ultra Mega Solar Power } \\
\text { Plant }\end{array}$ & NTPC & CENTRL & 500.00 \\
\hline $\begin{array}{l}\text { Kurnool Ultra Mega Solar Power } \\
\text { Plant }\end{array}$ & NTPC & CENTRL & 1000.00 \\
\hline Anantapuramu - II Mega Solr Park & APGENCO & STATE & 200.00 \\
\hline TOTAL: & & $\mathbf{6 7 1 0}$ \\
\hline
\end{tabular}

\section{IMPLEMENTATION OF THE PLANNED WORK}

In a live power framework, power plants aren't organized at an identical separation from the concentrate of burdens and their fuel prices square measure extraordinary. Likewise underneath standard operating conditions, the generating limit has to satisfy the wholeburden would like and misfortunes. Consequently, here, it shows the employment of symbolic logic controller to require of the difficulty of unit commitment and cargo planning with another age arrange with absolutely the age price may be upgraded. From section I \& II, the planned technique is dead with the MATLAB/Simulink condition and also the comparison FIS contribution of Power generating stations and membership

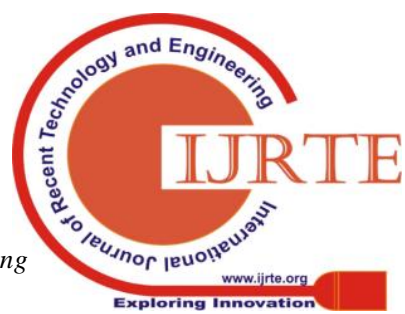


components of individual stacking on the generators of the frame work appeared in Fig one and Fig a pair of. From Fig 1, it's seen that the principal generator is in on position from $1 \mathrm{MW}$ ahead and at this position staying 2 generators square measure in hot enclose Position, second generator is in on position from 1000MW ahead and at this position staying one generator is in hot enclose Position, third generator is in on position from $3500 \mathrm{MW}$ ahead. At any heap position, each oneof the generators square measure in on position but relying upon the heap on the station, the generators square measure in on position or hot enclose Position. within the event that the heap on the station fluctuates with $10 \mathrm{MW}$ interim, at that time all out quantities of tests square measure five hundred. The planned Fuzzy methodology is empower to supply declare a heap on the station distinctive the number of generators needed to coordinate the given power request And what can be the manufacturing intensity of an each generator at that specific hour, during this method grappling the problems of Unit Commitment and cargo planning With ideal expense. thereupon the excellence within the expense older between ancient strategy and planned technique for various masses on the plant square measure appeared Table nine and also the comparison bar define as appeared in Fig three

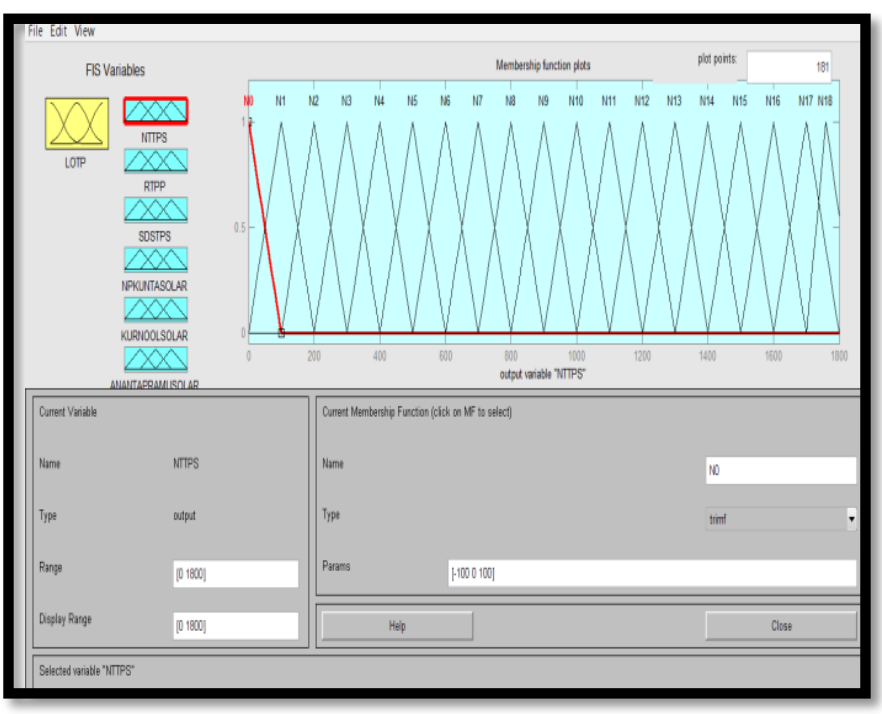

Fig 1: FIS input of Power Generating Stations

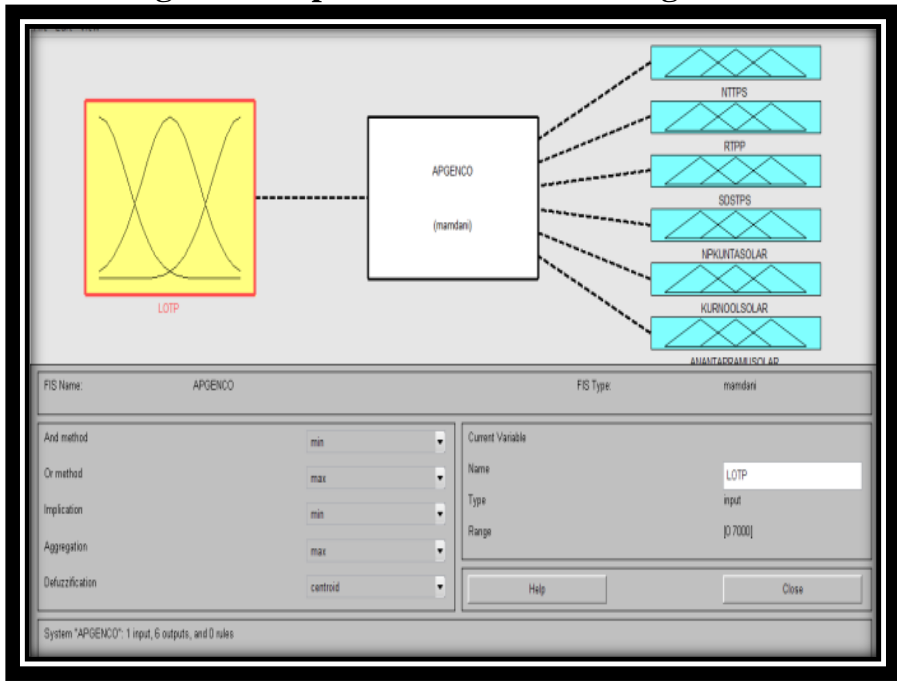

Fig 2.Membership functions of Individual loading on the Generators
Table 9: Comparison of Generation price with standard technique and planned technique considering solely Thermal Plants

\begin{tabular}{|c|c|c|c|c|c|c|c|}
\hline \multirow{2}{*}{$\begin{array}{l}\text { S } \\
\text { N } \\
\text { o }\end{array}$} & \multirow[t]{2}{*}{ LOAD } & \multirow{2}{*}{$\begin{array}{l}\text { W C M } \\
\operatorname{CoST}\end{array}$} & \multicolumn{4}{|c|}{$\begin{array}{l}\text { WITH PROPOSED METHOD } \\
\text { (LOAD SCHEDULING) }\end{array}$} & \multirow[t]{2}{*}{$\begin{array}{l}\text { SAVING S } \\
\text { (Rs) }\end{array}$} \\
\hline & & & $P S-1$ & $P S-2$ & $P S-3$ & $\operatorname{Cos} T$ & \\
\hline 1 & 500 & 2750 & 1 & 0 & 0 & 2750 & 0 \\
\hline 2 & 1000 & 5500 & 1 & 0 & 0 & 5350 & 150 \\
\hline 3 & 1500 & 8250 & 1 & 0 & 1 & 7750 & 500 \\
\hline 4 & 2000 & 11100 & 1 & 0 & & 10500 & 600 \\
\hline 5 & 2500 & 13975 & 1 & 0 & & 12250 & 1725 \\
\hline 6 & 3000 & 16850 & 1 & 0 & & 15000 & 1850 \\
\hline $7^{7}$ & 3500 & 19760 & 1 & 1 & 1 & 17000 & 2760 \\
\hline 8 & 4000 & 22760 & 1 & 1 & 1 & 20500 & 2260 \\
\hline 9 & 4500 & 25760 & 1 & 1 & & 24500 & 1260 \\
\hline $1 \begin{array}{l}1 \\
0 \\
0\end{array}$ & 5000 & 28760 & 1 & 1 & 1 & 28000 & 760 \\
\hline & & $1,55,465$ & & & & $\begin{array}{l}1,43,60 \\
0\end{array}$ & 11,865 \\
\hline
\end{tabular}

Table 10: Comparison of Generation price with standard technique and planned technique considering solely star Plants

\begin{tabular}{|c|c|c|c|c|c|c|c|}
\hline \multirow[b]{2}{*}{$\begin{array}{l}\text { S. } \\
\text { N } \\
\text { o }\end{array}$} & \multirow[t]{2}{*}{ LOAD } & \multirow{2}{*}{\begin{tabular}{|l}
$\mathrm{W} \mathrm{C} \mathrm{M}$ \\
$\cos T$
\end{tabular}} & \multicolumn{4}{|c|}{$\begin{array}{l}\text { WITH PROPOSED METHOD } \\
\text { SCHEDULING) }\end{array}$} & \multirow[t]{2}{*}{ SAVINGS } \\
\hline & & & $P S-1$ & $P S-2$ & $P S-3$ & $\cos T$ & \\
\hline 1 & 500 & 2950 & 1 & 0 & 0 & 2890 & 60 \\
\hline 2 & 1000 & 5950 & 1 & 0 & 0 & 5450 & 500 \\
\hline 3 & 1500 & 9155 & 1 & 0 & 1 & 8625 & 530 \\
\hline 4 & 1700 & 12250 & 1 & 1 & 1 & 12300 & 75 \\
\hline & & & & & & & 1,165 \\
\hline
\end{tabular}

Table11:Comparisonof Generation price with standard technique and planned technique considering each Thermal Plants

\begin{tabular}{|c|c|c|c|c|c|c|c|c|c|c|}
\hline \multirow[t]{2}{*}{ SNO } & \multirow[t]{2}{*}{ LOAD } & \multirow{2}{*}{$\begin{array}{l}\text { W CM } \\
\cos T\end{array}$} & \multirow[b]{2}{*}{$\begin{array}{c}P S- \\
1\end{array}$} & \multirow[b]{2}{*}{$P S-2$} & \multirow[b]{2}{*}{$\begin{array}{r}P S \\
-3\end{array}$} & \multicolumn{4}{|c|}{$\begin{array}{l}\text { WITH PROPOSED } \\
\text { METHOD }\end{array}$} & \multirow{2}{*}{$\begin{array}{c}\text { SAVIN } \\
\text { G } \\
\text { S }\end{array}$} \\
\hline & & & & & & $\begin{array}{c}P S \\
-4\end{array}$ & $\begin{array}{c}\text { PS- } \\
5\end{array}$ & $P S-6$ & $\cos T$ & \\
\hline 1 & 500 & 2750 & 1 & 0 & 0 & 0 & 0 & 0 & 2750 & 0 \\
\hline 2 & 1000 & 5500 & 1 & 0 & 0 & 0 & 0 & 0 & 5350 & 150 \\
\hline 3 & 1500 & 8250 & 1 & 0 & 1 & 0 & 0 & 0 & 7750 & 500 \\
\hline 4 & 2000 & 11100 & 1 & 0 & 1 & 0 & 0 & 0 & 10500 & 600 \\
\hline 5 & 2500 & 13975 & 1 & 0 & 1 & 0 & 0 & 0 & 12250 & 1725 \\
\hline 6 & 3000 & 16850 & 1 & 0 & 1 & 0 & 0 & 0 & 15000 & 1850 \\
\hline 7 & 3500 & 19760 & 1 & 1 & 1 & 0 & 0 & 0 & 17000 & 2760 \\
\hline 8 & 4000 & 22760 & 1 & 1 & 1 & 0 & 0 & 0 & 20500 & 2260 \\
\hline 9 & 4500 & 25760 & 1 & 1 & 1 & 0 & 0 & 0 & 24500 & 1260 \\
\hline 10 & 5000 & 28760 & 1 & 1 & 1 & 0 & 0 & & 28000 & 760 \\
\hline 11 & 5500 & 35000 & 1 & 1 & 1 & 1 & 0 & 0 & 35000 & 0 \\
\hline 12 & 6000 & 41250 & 1 & 1 & 1 & 1 & 0 & 0 & 41250 & 0 \\
\hline 13 & 6500 & 47000 & 1 & 1 & 1 & 1 & 1 & 0 & 47000 & 0 \\
\hline 14 & 7000 & 50000 & 1 & 1 & 1 & 1 & 1 & 1 & 500000 & 0 \\
\hline
\end{tabular}

Published By: 


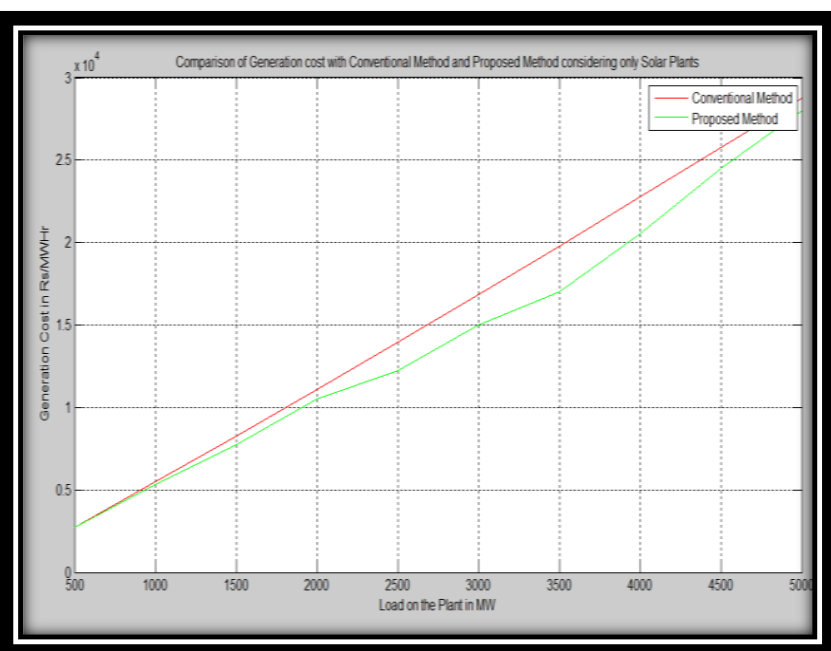

Fig 4: Comparison of Generation price with standard technique and planned technique

\section{RESULTS AND DISCUSSIONS}

The planned strategy is viewed as plan burden coming up with issue for booking thermal and sun primarily based generating units to limit the operating expenses. A MATLAB Program is generated for ideal burden coming up with of the plant by utilizing dynamic programming technique and symbolic logic controller is actualised thus on get ideal burden booking of the plant. The age pricenonheritable by the symbolic logic programming primarily based financial load dispatch arrangement technique adds up to Rs one,43,600/wherever the value add up to Rs one,55,465/- once the customery strategy is dead. this suggests, there's a stinting of Rs. 11,865 in age prices nonheritable that is indicated Table nine. At the purpose once the Load on the Generating Station is gently stacked or utterly stacked, there's no distinction between the traditional technique for burden sharing and planned strategy. Table tendemonstrates the Comparison of Generation price with standard technique and planned technique considering simply star Plants and it closes from results that price is something however a stimulating live then it goes regarding as a nature well disposed plant. Table eleven demonstrates the Comparison of Generation price with standard technique and planned technique considering each Thermal and star Plants and it infers that for ideal price, heat plant is changed on 1st later sun orienting plant. Whenever price is not a live then one will activate daylight primarily based plant originally pursued by heat plant. Whenever price could be a foundation then one willactivate heat plant pursued by sun primarily based plant

\section{CONCLUSIONS}

Manual calculation of burden booking issue includes considerably longer and every one things thought of same time, the calculation time increments with the enlargement within the amount of units within the plant. In any case, the programming strategy limits the calculation time a good deal and also the time remains extensively consistent in spite of range of units within the plant. Ideal burden booking gotten by utilizing symbolic logic Controller offers higher outcomes contrasted with ancient technique and Implementation of symbolic logic leads to the decrease of manufacturing price by an enormous add. The planned strategy may be stretched to $\mathrm{N}$ range of units of a Thermal Power even as sun orienting power Generating Station

\section{REFERENCES}

1. N. P. Padhy "Unit Commitment - A bibliographic Survey." IEEE Transactions on power systems, vol 9, no 2, pp 1196 - 1205, May 2004.

2. A.K.Ayoub and A.D.Patton, "Optimal Thermal Generating Unit Commitment," IEEE Transactions on Power equipment \& Systems, Vol 90, page no:1752

3. W. L. Snyder, H.D. Powel and J. C. Rayburn "Dynamic Programming approach to Unit Commitment." IEEE Transactions on power systems, vol 2, no 2, pp $339-350$, may 1987

4. Senthil Kumar and V.Planisamy, "A Hybrid Fuzzy Dynamic Programming Approach to Unit Commitment." IE(I) Journal

5. World Wide Web.apgenco.gov.in

6. K.Srikrishna, "Analytical Approach to resolution of Coordination equation for generating scheduling", pp254-257, Vol.67, June 1987. Journal of the Institute of Engineers (INDIA)

7. Coal primarily based Electricity Generation in Republic of India

8. APGENCO Power Generation price Manuals

9. Tariff Determination Methodology for Thermal Power Plants in Republic of India.

10. National productivity council volume on energy management 